\title{
The Ethics of Romance: Edward Bellamy and American Historical Fiction
}

\author{
WANG TIAO
}

\begin{abstract}
The author examines The Duke of Stockbridge: A Romance of Shays' Rebellion (1879), a historical novel written by Edward Bellamy (1850-1898) in order to examine the ethics of Romance in the treatment of historical fiction. Edward Bellamy, most famous for his socialist novel, Looking Backwards (1888), himself looks backwards to examine the popular rebellion during the early post-revolutionary American democracy before the US Constitution was established. The striking feature of this novel is the way that it superimposes the romance genre onto political and historical events. Using the ethical criticism of J. Hillis Miller, Martha Nussbaum, Alasdair MacIntyre, and others, the paper examines the romance genre in relation to virtue ethics to analyze the ethical impulse in Bellamy's historical novel. To what degree does romance - a literary genre that combines stock characters and stereotypical action - open itself up to analysis in terms of the "virtue ethics" of Nussbaum, MacIntyre, and others? To what degree does an analysis of Bellamy's novel in these terms allow us to understand what I call the "rhetorical ethics" of a critic like Miller? An examination of the Genteel Literary Tradition prevalent at the time of Bellamy's novel - as it manifests itself in language and historical representation - allows us to see more closely the relations among rhetoric, character and ethics in the historical novel.
\end{abstract}

Keywords: ethics; historical novel; Edward Bellamy; The Duke of Stockbridge

The romance, which deals with heroes, is intermediate between the novel, which deals with men, and the myth, which deals with gods.

- Northrop Frye, Anatomy of Criticism

\section{The Argument}

The epigraph comes from Northrop Frye's discipline-defining text, Anatomy of Criticism (1957), and it touches upon my first thought for studying historical fiction. I had originally planned in this essay to offer an argument that contrasts the heroism of Romance to the realism that is necessary to ethical seriousness 
by examining the way that Edward Bellamy (1850-1898), in his novel The Duke of Stockbridge: A Romance of Shays' Rebellion (1879), takes the morally serious situation of injustice and political rebellion and presents it in the form of Romance, which presents itself in a very different manner from the seriousness of ethical considerations. That lack of seriousness takes the trivial form of occasional misspellings of Shays' name in some reprintings of his novel and the much less trivial form of romanticizing politics and transforming historical figures facing deep moral choices (which include issues of life and death) into a romantic tale of courtship and love. But the more I pursued this topic, the more I realized that focusing on the historical and ethical issues concerning the Genteel Literary Tradition of the late nineteenth century in which Bellamy found himself and larger issue of the ethical implications of generic choices should take precedence over the close reading of the novel I had originally envisioned. Emerging from this "larger issue" is the question of the ethics of literary representation more generally, and what light a discussion of literary representation - in this case, a romantic representation of historical facts - might shed light on our understanding of ethics more generally.

\section{Shays' Rebellion}

To this end, this essay touches upon the relationships among literature, politics, genre, and ethics. As the anchor of this paper, it examines Edward Bellamy's historical novel, The Duke of Stockbridge: A Romance of Shays' Rebellion, in order to examine the ethics of romance in the treatment of historical fiction. Edward Bellamy, most famous for his socialist novel on an imagined future, Looking Backwards (1888), focuses this novel on the historical past, on post-revolutionary America in which the states were governed by the Articles of Confederation. Great unrest in these years after the defeat of the British by George Washington and the Continental Army brings into pronounced relief the relationship between the political and the ethical: it was a time, amply demonstrated in the novel, during which powerful men in urban political centers obtained landed wealth for themselves by manipulating the courts and the monetary system of the new, loosely governed Republic. This unrest and political instability was a major impetus for the ratification of the U.S. Constitution in 1788. The striking feature of this novel is the way that it superimposes the Romance genre onto political and historical events. More recently, in 2007, William Martin focuses on Shays' rebellion in a thriller rather than a romance novel entitled The Lost Constitution. In many ways, it is more appropriate to take up a rebellion in the context of a thriller than a romance insofar as a thriller focuses on a prominent 
aspect of rebellion, namely its action and violence, while romance, as a genre of that pushes towards reconciliation and love, seems altogether alien to rebellion. Both thriller and romance, however, eschew the moral gravity of rebellion, which historical fiction often captures.

Shays' Rebellion was an armed uprising, primarily in western Massachusetts, that took place in 1786 and 1787. It was an uprising of American farmers against state and local enforcement of tax collections and judgments for debt. In fact, farmers rose again local and state governments from New Hampshire to South Carolina, but the rebellion was most intense in Massachusetts, where bad harvests, economic depression, and high taxes threatened farmers with the loss of their farms. A veteran of the American Revolutionary War, Daniel Shays - a former captain in the Continental Army - led several thousand men in rising up against widespread economic injustices and suspension of civil rights, which included many evictions and foreclosures of Massachusetts homes and farmlands by the government in Boston. At one point the rebels attempted to capture the United States' national weapons arsenal at the U.S. Armory at Springfield. Shays' Rebellion was defeated in Massachusetts by a privately raised militia, but it prompted numerous national leaders (including George Washington, who came out of retirement to deal with issues raised by Shays' Rebellion) to call for a stronger national government to suppress both future rebellions and the local state corruption that might, as in Shays' Rebellion, give rise to armed resistance. In fact, the Constitutional Convention began sitting in May 1787, so there was some slight overlap between Shays' Rebellion - which wasn't closely coordinated across the many states in which uprisings occurred and the deliberation over the new American governmental structure. ${ }^{1}$

\section{The Genteel Tradition}

In the early 1960s Norman Mailer presented a talk at the Modern Language Association meeting that he later published under the title "Cannibals and Christians" that deals with what he calls "the Dynamic of American Letters." He begins by asserting that there "has been a war at the center of American letters for a long time" (1966: 96). The war in American letters, he notes, is a class war between an upper middle class looking for "a refinement of itself to prepare a shift to the aristocratic" and "a counter-literature whose roots were found in poverty, industrial society, and the emergence of a new class" (1966:

1 For a fine historical account of Shays' Rebellion and responses to it - particularly that of Washington - see Larson 2014: 78-84. 
96). Mailer goes on to define this war in literary terms - "Naturalism versus the Genteel Tradition it has been called" (1966: 98) - and to figure the warfare as that between Edith Wharton and Theodore Dreiser. But after the failure of Dreiser, Mailer suggests, the warfare itself degenerates into the opposition between cannibals and Christians, the "Camp" discourse of Terry Southern and the morality of Saul Bellow: "literature was down to the earnest novel and the perfect novel, to moral seriousness and Camp. Herzog and Candy had become the protagonists." (1966: 100)

What is striking about Mailer's discussion is the way that it raises up, in literary-generic terms, the issue of ethics, moral seriousness, and Camp. "Camp" is a term that is no longer as fashionable as it was the 1960s. It designates a social, cultural, and aesthetic style and sensibility based on deliberate and self-acknowledged theatricality. Camp aesthetics disrupt many notions of high and morally serious art by inverting aesthetic attributes such as beauty, value, and taste through an invitation of a different kind of apprehension and consumption. ${ }^{2}$ While it would be mistaken to take Romance, as Bellamy uses the term, to be "camp," it is instructive to contrast Romance - and particularly the Genteel Tradition in late nineteenth-century America that Bellamy is using as a guide for translating historical seriousness into popular middle-class art with high and moral seriousness. The difference between the two traditions both the Genteel Tradition and Naturalism Mailer describes and Romance and ethically-inflected historical fiction I will be describing - has to do with the manner in which practical politics might be understood in relation to fiction. Mailer bluntly describes such an ethico-political aspect of fiction as "power or the secrets of power": "In opposition to Dreiser," Mailer writes, "was the imperfectly developed counter-tradition of the genteel. The class which wielded the power which ran America," he says, "and the class which most admired that class, banded instinctively together to approve a genteel literature which had little to do with power or the secrets of power [...] a literature which had to do finally with the excellence of belonging to their own genteel tradition" (1966: 122). More recently than Mailer, Frank Lentriccia describes the "genteel poets and critics" of the 1890s in America as powerfully distinct from the poets and critics of "the Paterian nineties of British Aestheticism" insofar as they "valued purity above all, the rigorous evacuation from poetry of sensuousness and the sensual, and of any tendencies of social representation” (1994: xi). The Genteel writers, Lentriccia notes,

2 For a thorough account of "camp," see McMahon 2006. 
flew from the world that capital was making [...] and [from] the (then) avantgarde presence of realist and naturalist fiction and all the repulsive social references of this new writing: the classes, middle and lower, in uneasy relation and movement, America's new (and swarthy) immigrants, business, money, power, sex, divorce, and other distinctly non-ideal preoccupations of a postaristocratic literary world. [...] Of course, they were attacked - from Twain and Howells to Santayana, Van Wyck Brooks, and Mencken - for being out of touch: hopelessly nostalgic, prudish, feminine, all enervated lyric inwardness. In Santayana's unfair phrase for Emerson: they digested vacancy [...] [Still,] the genteel poets maybe digested vacancy. In fact, it's hard to say what they digested. They would have agreed, at any rate, that they were out of touch: they intended to be out of touch; it was the nature and function of poetry to be out of touch. (1994: xi-xii)

To be out of touch designates a refusal of contact with the relentless worldliness of ethics, and the genteel poets (and the Genteel Tradition of late nineteenthcentury America more generally) fled such worldliness to such a degree that Lentriccia asserts that their "odor was distinctly one of mildewed and dusty old books" (1994: xii). That is, where the Genteel Tradition fled, in its escape from the bustling worldliness of late nineteenth century America, was to the idealization of Romance and cliché.

The Nature of Romance, the Work of Ethics, and

\section{The Duke of Stockbridge}

In Anatomy of Criticism, Northrop Frye offers what has become a standard definition of Romance. "The essential difference between novel and romance," he writes,

lies in the conception of characterization. The romancer does not attempt to create "real people" so much as stylized figures which expand into psychological archetypes [...] That is why the romance so often radiates a glow of subjective intensity that the novel lacks [...] The novelist deals with personality, with characters wearing their personae or social masks. He needs the framework of a stable society, and many of our best novelists have been conventional to the verge of fussiness. The romancer deals with individuality, with characters in vacuo idealized by reverie [...] (1957: 304-05)

This definition of Romance nicely comports with the sense of Genteel Tradition suggested by Mailer and delineated by Lentriccia: its sense of "subjective 
intensity," reverie, above all examining "characters in vacuo" in a manner that suggests Santayana's notion of feeding off vacancy.

In The Political Unconscious, however, Fredric Jameson takes up Frye's definition of Romance to uncover the political and ethical dimensions of storytelling. "Frey's identification of narrative in general with the particular narrative genre of romance," he writes, "raises the apparently unrelated issue of genre criticism, which ... has in fact always entertained a privileged relationship with historical materialism" (1981: 105). Jameson is suggesting that the narrative form intersects with historical values so that we can read, as he does with Joseph Conrad, the ethical and political implications of choices and omissions in narrative form. What narrative chooses in storytelling reverberates in ethics. Thus, the fleeing of the Genteel Tradition is an ethical choice not to engage history, which is to say not to acknowledge the possibility of a "post-aristocratic literary world.” In order to touch upon how Bellamy's choice to portray Shays' Rebellion in the form of Romance constitutes a similar ethical gesture, I want to turn to the "work" of ethics.

To this end let me examine Aristotle's notion of "practical reason." I want to do so because it is clear that for Aristotle practical reasoning - the Greek term is phronesis - is "understanding that manifests itself in action" (Schleifer and Vannatta 2013: 58), and an important way to grasp the ethical dimension of literary narrative is to think of the writer's choice, such as the choice of genre, as an action with ethical consequences. Towards the end of After Virtue, Alasdair MacIntyre describes Aristotle's conception of practical reason in relation to tradition. It is the case, he argues,

that an adequate sense of tradition manifests itself in a grasp of those future possibilities which the past has made available to the present. Living traditions, just because they continue a not-yet-completed narrative, confront a future whose determinate and determinable character, so far as it possesses any, derives from the past.

In practical reasoning the possession of this virtue is not manifested so much in the knowledge of a set of generalizations or maxims which may provide our practice inference with major premises; its presence or absence rather appears in the kind of capacity for judgment which the agent possesses in knowing how to select among the relevant stack of maxims and how to apply them in particular situations. (1984: 223)

MacIntyre's argument, that the past makes future possibilities available for the present is a wonderful way of thinking about historical fiction: like fiction in general - and like ethics as I will describe it here - historical fiction occasions the thoughtful deliberation of what is to be. 
WANG

Moreover, the not-yet-completed narrative that MacIntyre mentions deliberately describes the manner in which The Duke of Stockbridge accomplishes two things. First of all, the novel attempts, as all historical novels do, to create a living sense of the past. But in Bellamy's case, The Duke of Stockbridge also attempts to address the present moment in American life of a profound transformation of American experience, which include: the closing of the frontier; the furious creation and consolidation of corporate capitalism (the Federal Reserve System was being debated just after the novel was published in 1879, and it was finally established in 1913); massive numbers of immigrants from southern and eastern Europe were coming to America; and, among the privileged classes, the Genteel Tradition was thriving. All but the last of these factors contributed to Bellamy's notable success, his novel Looking Backwards, which was second only to Uncle Tom's Cabin in numbers of sales in the nineteenth century. At the heart of MacIntyre's argument is the ethical capacity - measured in action - to recognize or imagine the "end" or "ends" which particular situations call for.

In this passage, then, MacIntyre is articulating the manner in which narrative - and particularly the provisional open-endedness of the "not-yet-completed narrative" that he describes, which is always a constitutive element of narrative itself - informs both ethics and writing. This is particularly important to my argument because it seems to me that the genre of Romance presents a closed system - an "already-completed narrative" - even while politics, ethics, and the historical materialism Jameson mentions are always open-ended. This is clear in the work of Martha Nussbaum, particularly in her engagements with Aristotle's practical reasoning. In Love's Knowledge she argues that "the content of rational choice must be supplied by nothing less messy than experience and stories of experience. Among the stories of conduct," she continues,

the most true and informative will be works of literature, biography, and history; the more abstract the story gets, the less rational it is to use it as one's only guide. Good deliberation is like theatrical or musical improvisation, where what counts is flexibility, responsiveness, and openness to the external [...] (1990: 74)

Now Romance is abstract in ways that fiction - and particularly historical fiction is not. It possesses the features that Frye suggested and that allows the Genteel Tradition precisely to "flee" from history itself: its sense of "subjective intensity," reverie, examining "characters in vacuo." Moreover, the archetypes that Frye and for that matter Jameson - discern in Romance are precisely the opposite of the intense perception that Nussbaum sees as the most important element 
of engaged ethics. That is, it is no accident that Nussbaum entitles the chapter of Love's Knowledge that I am quoting "The Discernment of Perception" and later describes "an Aristotelian perception-based morality" (1990: 165) because "practical insight," as she says, "is an ability to recognize the salient features of a complex situation" (1990: 74). The aim of perception is "that of focusing on some concrete particular, either present or absent, in such a way as to see (or otherwise perceive) it as something, picking out its salient features, discerning its content" (1990: 77).

In her analysis of Aristotle, she is following the lead of David Wiggins, who notes that in moral deliberation,

the relevant features of the situation may not all jump to the eye. To see what they are, to prompt the imagination to play upon the question and let it activate in reflection and thought-experiment whatever concerns and passions it should activate, may require a higher order of situational appreciation or, as Aristotle would say, perception (aisthēsis). (1980: 233)

Perception, then, is the perception - and the "experience" - of the "the salient features" of a situation (Nussbaum 1990: 74) and, as Wiggins notes, "it is the mark of the man of practical wisdom ... to be able to select from the infinite number of features of a situation those features that bear upon the notion or ideal of existence which it is his standing aim to make real" (1980: 236). Nussbaum also notes that "it is no surprise to find [Aristotle] invoking ["imagination"] in connection with the minor premise of the 'practical syllogism,' that is, the creature's perception of an item in the world as something that answers to one of his or her practical interests or concerns" (1990: 77). Both, then, conceive of the activity of ethical deliberation to be the choice or discovery - the perception or discernment - of what is important (i.e., "salient") in a particular situation. In fact, this constitutes the open-endedness of ethical deliberation. But archetypes work differently: they do not provoke deliberation but command assent to "forms" that are not historical but transcendental: the "stylized figures," not the historical "personalities," of narrative. In this, Romance, more than most genres, is organized around a system of rules.

Nussbaum argues, however that "experience" - end the ethical activities growing out of experience - "is concrete and not exhaustively summarizable in a system of rules" (1990: 75). In the same way, narrative fiction remains provisional and "not-yet-completed" in its final interpretations. But Romance, as a genre, is complete. Thus, by re-imagining Shays' Rebellion as a Romance, Bellamy is, in effect, offering an ethical contradiction. The aim of historical fiction is to give the present a "living sense" of the past, a good approximation of how people, 
living in a different time, might have experienced and understood their lives; to create the possibility for the present readers to deliberate over the political and ethical considerations that faced people long ago; and to allow people to draw analogies between their own time and the time that the historical fiction focuses upon. Romance does none of these things, which is perhaps why it appealed to the Genteel Tradition as a vehicle precisely to escape from these things. Bellamy, however, wanted to do these things: these are the aims - and to an important degree the achievement - of Looking Backwards, and I can reasonable assume that "looking backwards" to a moment of resistance and armed rebellion against injustice was precisely his purpose in The Duke of Stockbridge. Yet representing that time in a Romance undercuts this purpose, to the degree that it speaks to - and seemingly attempt to join - the Genteel Tradition.

As we all know, Looking Backwards is a utopian novel about looking forward: Bellamy imagines a socialist utopia a hundred years in the future, and his main character, Julian West, looks "backwards" at the world he has left. As I have argued, such "looking forward" is the work of ethics, its "deliberation" and its purpose. And I have suggested here that such "looking forward" is the work of literary narrative insofar as fiction offers future possibilities to be considered. This is also the work of historical fiction: to look backwards to the past in order to deliberate about the future for individuals (as they learn about moral possibilities for themselves through the vicarious experience of fiction) and for larger social groups. The work of Romance, however, is different. It aims, as Frye and Jameson suggest, at presenting archetypes which, by definition, are "complete." This is the contradiction that haunts The Duke of Stockbridge: namely its attempt to provoke ethical deliberation in a narrative form that cuts it off. I hope, then, by offering a general discussion of literature, politics, and genre, I have shed light on the future orientation - the not-yet-completed narrative - of ethics itself, and in doing so to suggest the essential ethical nature of literary narrative.

\author{
Wang Tiao \\ lucyclass6@hit.edu.cn \\ P.O. Box 443 \\ 92 West Dazhi Street \\ Nangang District \\ Harbin, 150001 \\ Heilongjiang Province \\ CHINA
}


The Ethics of Romance: Edward Bellamy and American Historical Fiction

\section{Works Cited}

Frye, N. 1957. Anatomy of Criticism. Princeton: Princeton University Press. Jameson, F. 1981. The Political Unconscious. Ithaca: Cornell University Press. Larson, E. 2014. The Return of George Washington: Uniting the States, 1783-1789. New York: Harper Collins.

Lentriccia, F. 1994. Modernist Quartet. Cambridge: Cambridge University Press. MacIntyre, A. 1984. After Virtue. Notre Dame: University of Notre Dame Press. McMahon, G. 2006. Camp in Literature. Jefferson, NC: McFarland \& Company. Mailer, N. 1966. Cannibals and Christians. New York: Viking Press.

Nussbaum, M. 1990. Love's Knowledge. New York: Oxford University Press.

Schleifer, R., Vannatta, J. 2013.The Chief Concern of Medicine. Ann Arbor: University of Michigan Press.

Wiggins, D. 1980. Deliberation and Practical Reason. - A. Oksenberg Rorty, ed., Essays on Aristotle's Ethics. Berkeley: University of California Press, 221-240. 